\title{
Governance, Restructuring and the New Public Management Reform: South African Perspectives
}

\author{
Nyawo Gumede \\ Tshwane University of Technology, South Africa \\ gumedenb@tut.ac.za \\ Kenneth B. Dipholo \\ (Dr), University of Botswana, Botswana \\ dipholok@mopipi.ub.bw
}

\section{Doi:10.5901/jesr.2014.v4n6p43}

\section{Abstract}

In the last two decades an array of management techniques and practices have been adopted and implemented by most governments to ameliorate public administration. This was principally because most governments got ensnared in huge debts, operational inefficiency, and ineffectiveness in service delivery including lack of accountability from political elites and public servants. These problems emanated from the quaint methods of fiscal management that were implemented and practiced resulting in rampant corruption and feeble public services. This led to widespread disgruntlement and demand for good governance hence the rise of the New Public Management (NPM). Theories like public choice theory and principal-agent theory propelled the rise of the New Public Management (NPM) with its consonant reforms and practices of restructuring. The colonial-independence-globalization theory also gave impetus to the emergence of the NPM theory for most former colonies like South Africa which had colonialism of a special type. Most African countries including South Africa have socio-political and economic conditions different from their Western counterparts because of decades of colonialism and apartheid and therefore experienced NPM uniquely. This paper explores the concepts of governance, restructuring and the NPM in the context of South Africa.

Keywords: Governance, New Public Management, Restructuring Reform, Corruption

\section{Introduction}

Public management has witnessed so many changes since the 1980s. Critical debates on good governance and its requirements have precipitated novel approaches to public sector management reforms. Governance failures and endemic corruption in most post-colonial African states propelled debates on new forms of governance. Most governments are personalized and are characterized by systemic corruption, nepotism, bureaucratic red tape and lack of proper delegation leading to ne-man rule. Principles of good governance are totally and absolutely lacking. The World Bank recognizes the following four elements of good governance: a) Public sector management emphasizing the need for effective financial and human resource management through improved budgeting, accounting and reporting and rotting out inefficiency particularly in public enterprises (through restructuring); b) Accountability in public services, including effective accounting, auditing, and decentralization and generally making public officials responsible for their actions and responsive to consumers; c) A predictable legal framework with rules known in advance (a reliable and independent judiciary and law enforcement mechanisms) and d) Availability of information and transparency in order to enhance policy analysis, promote public debate and reduce the risk of corruption (World Bank, 2002).

Governance emphasizes on ameliorating public sector management systems to enhance efficiency, effectiveness, productivity and competitiveness in service delivery. Thus, in good governance prescriptions public management reforms are a key aspect in the quest for market-based and private-domain-based paradigms to public sector management with a flavor called New Public Management (NPM). NPM has characteristics rooted in private sector frameworks of competitiveness, entrepreneurialism and customer satisfaction. In fact NPM is a label utilized to depict a managerial culture that emphasizes the centrality of the citizen or customer as well as accountability for results. It is a set of broadly similar administrative doctrines which were the focus of public administration agenda of most Organization for economic Cooperation and Development (OECD) countries from as far back as 1970 (Hood, 1991). The key components of the 
NPM may be put into two broad classes namely, those that emphasize managerial improvement and organizational restructuring, and those that emphasize markets and competition. Improved efficiency, greater competitiveness and accountability are the overriding aim of public sector reforms in South Africa since 1994. Strengthening anti-corruption mechanisms and institutions has been another important development in an attempt to reform. South Africa also made efforts to restructure most Sate Owned Enterprises (SOEs) to improve their financial and economic performance especially after 1997. It is significant to note that contemporary reforms have largely focused on the public sector with government aiming to introduce greater effectiveness, transparency, accountability and efficiency in the public service. Public sector restructuring and in particular restructuring of State Owned Enterprises has thus become not only a global phenomenon, but an integral part of the South African culture.

\section{Background}

Governance is the practice and exercise of power in decision making in all spheres of government. Governance involves different stakeholders in the public policy arena ranging from the ruling political elites, the private sector, and supranational organizations like the World Bank, IMF, the WTO and the UN. In South Africa, government is comprised of three spheres, namely National Provincial and Local government. South Africa has nine provincial governments and a plethora of local municipalities, which are both urban and rural. Municipalities govern on a four year term basis and run local affairs subject to national and provincial legislation but the latter may not compromise or impede a municipality's right to exercise its powers or perform its functions. In line with the principles of cooperative government, national and provincial government spheres are constitutionally mandated to strengthen municipalities' capacity to engage in local governance. However, metropolitan municipalities like Ekurhuleni Metro, EThekwini Metro and Tshwane Metro, Nelson Mandela Metro, Cape Town and Johannesburg Metro Municipalities have municipal executive and legislative authority in their juridical localities hence are at liberty to utilize the mayoral executive system or committee system.

After the restructuring of local government around 2005, South Africa had about 284 municipalities (Stats, SA, 2005). These municipalities play a key role in local government particularly in the delivery of public services. Nevertheless, weaknesses in services delivery manifest themselves easily at local level because local government has immediate responsibility to provide services that are mostly basic to local communities. Ineffectiveness and inefficiency in governance is felt at the local sphere of government than at the national, largely because the welfare of the citizens in these communities depends on the decisions made by local government.

\section{Understanding the Concept of Governance}

The World Bank defines governance as the manner in which power is exercised in the management of a country's economic and social resources. The World Bank has thus identified three distinct aspects of governance namely: a) The form of political regime; b) The process by which authority is exercised in the management of the country's economic and social resources for development; and c) The capacity of government to design, formulate and implement policies and discharge functions (World Bank, 2002).

On the other hand, UNDP views governance as the exercise of economic, political and administrative authority to manage a country's affairs at all levels. UNDP posits that governance comprises mechanisms, processes, and institutions through which citizens and groups articulate their obligations and mediate their differences (UNDP, 1995). From the OECD perspective, governance denotes the use of political authority, and exercise of control in a society in relation to economic development (OECD, 1995). Thus, all these definitions encompass the role of public authorities in establishing an environment in which economic operators function and the nature of the relationship between the ruler and the ruled. For instance, in South Africa the tripartite Alliance of the African National Congress (ANC), South African Communist Party (SACP) and Congress of South African Trade Unions (COSATU) exercise considerable influence over policy issues even though at times they differ substantially as exemplified by the debate on nationalization of mineral resources.

Governance concepts mark a shift away from state control and state interventionist models of government to a minimalist state that is only concerned with provision of basic goods and services such as defense, education and health (Mothusi \& Dipholo, 2008). It is significant to note that in most Third World countries like South Africa, the ruling elite tends to assume absolute power and authority in the governance process. Thus, dissenting views are often squashed. Domination by a single political party has led to political elites staying in the governance seats for a considerable length of time. For instance, in Angola the president has ruled for many decades in excess of generally accepted two terms of 
five years a term. In Namibia the former President extended his two terms by another term after amending the constitution. Most of these leaders see themselves as royals as opposed to elected officials and therefore want to govern for a lifetime resulting in failed states due to a combination of factors such as outright failure to govern, corruption, complacency and so forth.

Perspectives on the emergence of governance can be traced at the country level to a disgruntlement with statedomination models of economic and social development so prevalent throughout the socialist bloc and much of third world in the 1950s, 1960s and 1970s. At the international level, global governance, can be traced to a growing dissatisfaction among streams of international relations with the realist and liberal-institutionalist theories that dominated the study of international organization in the 1970s and 1980s (Weiss, 2000).

\section{Good Governance: The South African Perspective}

Good governance is expected to propel economic growth and development. From a critical perspective, South Africa is a middle income country with pockets of first world characteristics, such as infrastructure and some extremely opulent segments of the population. On the other hand, the majority of people constituting more than $85 \%$ of the country's population who live in the rural areas are extremely poor. This situation is not likely to change unless principles of good governance are practiced at all spheres of government and in all state institutions including its public enterprises. Good governance entails competent management of state resources be they natural, physical and financial as well as greater accountability by the government.

Through the Reconstruction and Development Programme (RDP), the government of South Africa has built and distributed many houses for the poor although the programme is dogged by institutional and systemic corruption in the actual construction as well as the allocation of the RDP houses. Nepotism is also rampant and has negatively affected the judicious allocation of RDP houses to the poor in provinces like Eastern Cape, Limpopo Mpumalanga and Kwazulu/Natal. The awarding of tenders for government projects in South Africa has been heavily criticized by scholars for being corrupted by a few political elites for personal benefits. South Africa has been criticized for corruption that is widely practiced in all spheres of government especially during the post-Mandela era. When corruption, either institutional or systemic, is left unchecked by a country, the result is poor governance.

\subsection{Key elements of Good governance}

\subsubsection{Political Principles}

a) Good governance is based on the establishment of a representative and an accountable form of government;

b) Good governance requires a strong and pluralistic civil society, where there is freedom of expression and association;

c) Good governance requires good institutions - sets of rules governing the actions of individuals and organizations and the negotiation of differences between them;

d) Good governance requires the primacy of the rule of law, maintained through an impartial and effective legal system; and e) Good governance requires a high degree of transparency and accountability in public and corporate processes (Downer, 2000).

\subsubsection{Economic Principles}

a) Good governance requires policies to promote broad-based economic growth, a dynamic private sector and social policies that will lead to poverty reduction. Economic growth is best achieved in an efficient, open, market based economy; b) Investment in people is high priority, through policies and institutions that improve access to quality education, health and other services that underpin a country's human resource base; c) Effective institutions and good corporate governance are needed to support the development of a competitive private sector. In particular, for markets to function, social norms are needed that respect contract and property rights; and d) Careful management of the national economy is vital in order to maximize economic and social advancement (Downer, 2000).

Good governance differs from one country to the other. In the same way, good governance issues and priorities differ from one political culture to the other. 


\section{The New Public Management (NPM) concept in South Africa}

Globally NPM emerged in the 1980s as benevolent critic to the traditional public administration. Prior to prior the emergence of NPM paradigm, public administration was seen as the most rational avenue for managing the affairs of the public. However, Obsorne and Gaebler (1992) opine that there was a need to reinvent government and harness the entrepreneurial spirit to transform the public sector and later "banish the bureaucracy". This pointed clearly to the need to restructure government bureaucracy to promote productivity, competitiveness, and efficiency and effectiveness.

In South Africa, bureaucratic red tape is affecting most government departments. Since the early 1990s, South Africans across the political and professional divide have expressed grave concern about governmental efficiency, effectiveness and competitiveness in service delivery. With the creation of a single public service after 1994 that resulted from the merging of the four states of the Transkei, Bophuthatswana, Venda and Ciskei that were established by the apartheid regime for black people and the self-governing territories, government bureaucracy became too large and extra-ordinarily hierarchical. Public Administration became a source of poor service delivery.

It is worth noting that South Africa embraced the democratization process as an impetus for public sector reforms and liberalization of the markets. Thus, the process of decentralization was formalized with the constitutional establishment of local government and provincial governments. The rationale for decentralization is that local government is closer to local communities hence better placed to respond to their needs timely. However, between 1994 and 2010 the South African government has failed to take full advantage of the new wind of change thrust upon by the NPM vibe. Thus, South Africa still suffers from bureaucratic red tape, systemic corruption, inefficiency, ineffectiveness, poor service delivery, poor accountability and nepotism particularly in the award of government tenders to political dynasties of former liberation movements who claim their legitimacy from the liberation struggle. Due to this liberationdynasty syndrome, appointment of senior personnel especially at the level of Director-General, Deputy Director General and even at Chief Director is not based on merit. Thus, in most departments the whole operational stratum is politically corrupted leading to low productivity as a result of shortage of skills. This syndrome also affects the way procurement is done as exemplified by the recent police buildings saga which led to the withdrawal and removal of the Police Commissioner from the office and the former minister of public works in South Africa.

Essentially, NPM is a management culture that emphases the centrally of the 'customer', as well as accountability for results. The main objective of implementing NPM is to achieve more transparency, more efficiency and more quality as well as reduction of expenses. As a tool of public sector reform, NPM consists of several elements. Reformers from all parts of the world can avail all these elements as fundamental tools in transforming the public sector. These elements include the following:

a) Lean state - reduced tasks performed by state;

b) Separation of decision making levels - separation of the strategic from the operative level: politics decides the what, administration the how;

c) Lean management - combination of management by objectives, flat hierarchy, projects management, performance related payments, modern methods of leadership;

d) New services attitude - customer orientation: satisfaction in the center of all consideration, behavioral changes;

e) New model of control - steering by clear targets, measurement of results, transparency of resources allocation:

f) Decentralization - tasks ,responsibility, competence and budget in the hand of the projects manager I department manager;

g) Quality management - ensure high service quality through qualification, competition, transparency; and

h) Product approach - describing all administration services as "products" highlighting factors such as: features, cost, needed resources, and time to deliver (Teehankee, 2003).

It should be noted that these elements of the New Public Management philosophy shore up or act as pillars of good governance. However, because of the incompetence of the human capital in South Africa, the NPM principles are not implemented objectively. Most senior public servants are inadequately trained or educated and are mostly appointed on the basis of political patronage or along tribal lines hence they are not able or are unwilling to appreciate the core principles of good governance. Most liberation activists who obtained communist/socialist education/training during the struggle against apartheid rule dominate the public service, yet many have questionable qualifications and in some extreme cases have none at all.

The government may have many good policies for public sector reform but effective implementation is weak owing 
largely to corruption that often results in the employment of unqualified personnel. The emergence of the NPM theory is associated with increasing popular and intellectual disenchantment with the growth and role of government and increasing taxation and consequently, pressures to curb the expansion of government and shift towards privatization (Larbi, 2003). Public choice theory has disapproved Max Weber's model of bureaucracy for its lack of costconsciousness because of weak links between costs and outputs (Larbi, 2003). For instance, it has been argued that the performance reward system in the public sector of South Africa is not geared towards improving performance and as a result there are no incentives for politicians and bureaucrats to control costs of government operations at all spheres of government especially after 1994. The corollary of this is flagrant fiscal waste and over-expenditure because politicians interfere with the system to benefit votes during election time at the local, provincial and national sphere of government.

Productivity, efficiency, effectiveness and competitiveness are not immediate priorities of the public servants in South Africa. Public choice theory contends that public administration is very slow and suffers from lack of greater responsiveness, allocative inefficiency, distributive incapability and weak re-distributive efficacy in South Africa. The principal-agent theory argues that the public (as principals), on whose behalf politicians and bureaucrats (as agents) are supposed to govern, is unable to hold the latter accountable because of insufficient information, (information asymmetry), incompleteness of the contracts of employment and the problems of monitoring behavior (Larbi, 2003). The public sector under performs because state officials pursue their narrow self-interests rather than the public interest. It is therefore difficult to demand accountability and good performance from the public servants (agents) because of the monopoly of public services, imperfect information about the services and about the interest of public employees and the huge transaction costs that would be involved in the efforts to write and monitor complete contracts (Larbi, 2003). It is critical to foster competition in the delivery of public services and reduce monopoly of the traditional government on public services. Larbi (2003) concedes that the result of the above drivers for change is that the role and institutional character of the state have been under increasing pressure to be more market-oriented and management-oriented with the emphasis on doing more with less (Larbi, 2003).

The traditional model of organization and delivery of public services based on the principles of bureaucratic hierarchy, planning, centralization, direct control and self sufficiency is being replaced by the NPM model (Larbi, 2003). The policy framework in South Africa is a graveyard that officials and people walk on without realizing it unless and until they fall on top of a skeleton. There are policies that are very contradictory and inconsistent with a developmental state trajectory with many being formulated in isolation with one another with particular regards to their objectives and implications. This is poor governance at its best. Many policies are not sustainable, not futuristic and environmentally insensitive largely because they are not based on realities on ground but rather on political expediency and convenience. Restructuring programmes, while a feature of the new public management concept, are poorly implemented by corruptly appointed government consultants who end up doing substandard job. The effort to reform public enterprises with emphasis on their financial and economic performance is typical of public management reform.

Another conjecture which stimulated and propelled the rise of the NPM is what may be termed the colonialindependence-globalization phenomenon which traces the philosophy of public administration in South Africa from the colonial period through to the present day. This perspective contends that colonial apartheid public administration was very rigid, hugely- bloated, and acutely geared towards material exploitation and extraction of resources and creations of colonial markets, with very little interest on improving the quality of life for the colonized. This was achieved mainly through institutionalized autocratic administration. From Anglo-phone Africa, Franco-phone and to Luso-phone countries dictatorial administration of the proportions of a police state was common. In particular, apartheid South Africa practiced autocracy based on the Webarian model of organization that has no respect for the NPM principles. Racial segregation did not permit equitable, transparent, effective and competitive allocation and management of public resources. Public administration served narrow and rigid interests.

The urge to adopt NPM principles at independence was apparent with the adoption of the democratic and transparent constitution of South Africa. Thus, decentralized spheres of government were adopted to democratize public administration and give South Africa a renewed impetus for good governance. The new nine basic values and principles governing public administration were incorporated in the new constitution. The Public Finance Management Act of 1999, the Preferential Procurement Policy Framework Act of 2000, the Preferential Procurement Regulations of 2001and the Municipal Finance Management Act of 2003 are all pieces of legislation which embrace the principles of the NPM trajectory. The wave of globalization also injected added impetus for the rise of NPM theory. From the colonial apartheid public servants to post independence civil servants, the need to globalize public services meant accepting the NPM. Global best practice became the brazen buzz word amongst government bureaucrats and consultants. The shift from Reconstruction and Development Program (RDP) to GEAR (Growth Employment and Redistribution) and New Growth 
Path is a clear sign of the victory of NPM principles in the new democratic South Africa. Given the foregoing it is clear that the colonial-independence-globalization phenomenon has taken the NPM paradigm to novel levels in the history of public administration. In a bid to ameliorate service delivery efficiency, effectiveness, productivity and competiveness the post independence bureaucrats have no choice except to adhere to global best practice which is NPM trajectory.

\section{Restructuring of State Owned Enterprises in South Africa}

The constitution of the Republic of South Africa requires the state to engage in pro-active action in the process of socioeconomic growth and creation of social balance in South Africa. The constitution makes it clear that the state can make reforms as far as macro-economic growth is concerned. State Owned Enterprises (SOEs) in South Africa play a pivotal role in the process of economic development. Major state-owned-Enterprises in the transport, telecommunications, energy and defence must support the vision of the state towards global economic competitiveness, competency, competition and development. Success stories from countries that achieved unprecedented levels of economic growth such as the South East Asian Tigers have pushed the rest of the developing world into accepting the idea of state assets restructuring as a means of improving their efficiency (Naledi, 1999). From the forgoing it is clear that restructuring is a key feature of the NPM theory. Since 1994, the goals of restructuring have been embraced to address problems of inefficiency and ineffectiveness in the public sector, though government's objectives of economic development have been refined from time to time. The objectives for restructuring reform are inter alia;

a) To facilitate economic growth;

b) To fund the RDP (Reconstruction and Development Programme);

c) To create wider ownership in the South African economy through black economic empowerment and boosting the small and medium enterprise sector;

d) To mobilise private sector capital;

e) To reduce state debt (proceeds may be used to reduce state debt from the apartheid era);

f) To enhance the competitiveness of state enterprises (open up accessibility to global markets);

g) To promote fair competition; and h) To finance growth and requirements for competitiveness (Policy Framework, 2000).

These objectives clearly show a commitment by the government to adhere to the principles of the NPM and good governance at enterprise level. The objectives are a mirror reflection of utmost commitment to improving the economic and public sector landscape. There is an inescapable demand for new financing through different forms of domestic and foreign partnerships to promote infusion of new equity capital and especially technology. It should be emphasized that growing enterprises are essential to ensure job security for the employed and to generate new employment opportunities for the unemployed (Policy Framework, 2000). It is important to note that economic growth and redistribution are central to the government objectives. The restructuring of state-owned enterprises (SOEs) is expected to lead to weakening of state control and authority over the provision of services, what may be called the thinning of the state (Terry, 2005). It is expected that the reform will capacitate markets and improve the delivery of services. Most state-owned enterprises in South Africa find themselves in huge debts hence the need to restructure to cushion them against further indebtedness while at the same time creating economically viable entities. Once the state asset is debt-free it is able to participate in economic development without restraint because its financial base would be healthy.

However, development cannot be measured only by financial criteria and restructuring is not a means of improving government finances and enterprise at the expense of the poor (ANC, 1994). Rather, the success of restructuring will be measured by its contribution to improving the standard of living of the South African citizens. The state has created an enabling framework such as regulatory reforms and institutions, which facilitates the process of the restructuring of stateowned enterprises and ultimately economic development. State Owned Enterprises (SOEs) play a crucial role in the current phase of economic restructuring where the focus shifts from macro-economic stability to the development of a sustainable growth trajectory.

In order for South Africa to enter competitively into the global environment growth sectors need to be effectively supported primarily by dominant economic role players, which include the energy, telecommunications and transport sectors (Policy Framework, 2000). Restructuring of these corporations normally contribute significantly to improving the overall competitiveness, productivity, globality and competency of the economy from a micro, meso and macro-economic perspective. Restructured state-owned-enterprises (SOEs) play an important developmental role in South African society via the integration of public, private and social capital and expertise. The objectives of restructuring broadly cover those state owned enterprises where the government can influence company, industry and broader economic objectives (New 
Agenda, 2002). At the company and industry level, restructuring involves improving the efficiency and effectiveness of the entities in question, accessing global competitive technologies and expertise, and assisting in the creation of effective market structures. At the macro-economic level, the government recognise the need to attract foreign direct investment, to manage the country's public borrowing requirements responsibly and to assist the development of an economic context that promotes industrial competitiveness and growth.

Overall, restructuring of State-Owned Enterprises seeks to enhance greater accountability and transparency which is clearly a feature of the NPM approach (Naledi, 1999). On the social front, social imperatives include growth in employment, wider ownership and participation in the South African economy. Private public infrastructure partnerships in many sectors have already been manifested in the partial privatisation of Telkom, ACSA and South African Airways (SAA). Thus, State Owned Enterprises (SOEs) represent a critical element of the South African economy. Through the instrumentality of the restructuring programmes, the government of South Africa aims at creating a market-driven reform and economic milieu, largely supported by private, public and social capital (Policy Framework, 2000). This process attracts investors locally and hemispherically and competition forms a central element in the restructuring of State Owned Enterprises. Given the prevalence of residual natural monopolies in (SOE) sectors and the size of (SOEs) in relation to potential local competitors, the aim of government is to ensure that restructuring leads to greater competition with an appropriate degree of regulation. (New Agenda, 2002)

\section{Conclusion}

This paper has explored the concepts of governance, good governance, new public management and restructuring initiatives. However, the greatest irony of our times is that while the government of South Africa makes remarkable strides to embrace the principles of the New Public Management thus reforming the public sector, institutionalised and systemic corruption that is endemically entrenched in government defeats the purpose of reform. Many members of the political elite collude in defrauding government and the general public. As a result and like in most emerging economies, South Africa has serious problems of lack of good governance. The rule of law should be observed if good governance is to be entrenched in the South African culture. The liberation-dynasty syndrome has negatively affected the theory and practise of public administration and management in South Africa because elite segments of the public service who come from the liberation background dominate the appointment process of senior managers in the post-apartheid epoch through the so called cadre deployment policy of the ruling party. Thus, it is inherently difficult for qualified, competent and skilled people to work and contribute in the public service. This challenge has to be tackled head-on in order to promote and sustain good governance in South Africa.

\section{References}

African National Congress. (1994). White paper on Reconstruction Development Program. Pretoria. Luthuli House.

Downer, A. (2000). Good governance: Guiding principles for implementation. Canberra. USAID.

Hood, C. (1991). A Public Management for all seasons? Public Administration. Vol. 69 (4), 3-19.

Kikeri, S., Nellis, J. \& Shirly, M. (1992). Privatization: The lessons of experience. Washington, DC, World Bank.

Republic of South Africa. (2005). Statistics South Africa, Government Printer, Pretoria.

Larbi, G. A. (2003). United Nations Research Institute for Social Development, Discussion paper 112.

Mothusi, B. \& Dipholo, K. (2008). Privatization in Botswana: The demise of a developmental state? Public Administration and Development. Vol. 28 (4), 239-249.

National Labour and Economic Development Institute (Naledi). (1999). Restructuring of State of Assets. An Assessment. Naledi, Braamfontein.

New Agenda .(2002). Journal of Economic Policy, Capetown, Institute of African Alternatives

OECD. (1995). Governance in Transition: Public Management Reforms in OECD. OECD Publishing.

Okafor, T. G. (2012). Public Sector Financial Records Management: A panacea for good governance. An international journal of Arts and Humanities. Vol. 1 (1), 68-78.

Osborne, D and Gaebler, T. (1992). Reinventing Government: How the Entrepreneurial Spirit is Transforming the Public Sector. New York: Penguin Books.

Republic of South Africa. (2005). Statistics South Africa. Pretoria: Government Printer.

Republic of South Africa \& UNDP. ( 2000). Policy Framework: An accelerated agenda towards the restructuring of State Owned Enterprises. Ministry of Public Enterprises: Pretoria.

Teehankee, J. C. (2003). New Public Management: Lean State, Lean Government, Seminar paper presented on February 9-16.

Terry, L. D. (2005). The thinning of administrative institutions in the hallow state. Administration \& Society. 37 (4), $426-444$.

United Nations Development Programme. (1995). Public Sector Management Governance and Sustainable Human Development. New 
York: UNDP

Weiss, T. G.(2000). Governance, good governance and global governance: Conceptual and actual challenges. Third World Quarterly. 21 (5), 795-814.

World Bank. (2002). Reforming Public Institutions and Strengthening Governance: A World Bank Strategy. New York. 